\title{
Pulmonary Necrosis in a COVID-19 Patient
}

\section{Luis Enrique Núñez Moscoso* | Giovanna Zúñiga Lazo | Karin Pacheco Trigozo}

Emergency Department, Hospital Nacional Carlos Alberto Seguín Escobedo - EsSalud Arequipa - Perú

*Correspondence: Luis Enrique Núñez Moscoso

Address: Emergency Department, Hospital Nacional Carlos Alberto Seguín Escobedo - EsSalud Arequipa - Perú

e-mail $\bowtie$ : lnunez10@hotmail.com

Received: 19 February 2021; Accepted: 22 February 2021

Copyright: (C) 2021 Moscoso. This is an open-access article distributed under the terms of the Creative Commons Attribution License, which permits unrestricted use, distribution, and reproduction in any medium, provided that the original work is properly cited.

\section{Clinical Image}

Male patient 48 years old that have been evaluated for tracheitis in July 24th (Fig. 1: Chest rx) with few alterations. That week begins with fever, malaise, cough and difficulty breathing. That time he was attended in a local private institution for 5 days. There he took a chest tomography (Fig. 2) at August 1st. Laboratory findings showed ferritin level of $>2000 \mathrm{ng} / \mathrm{ml}$; C reactive protein $85 \mathrm{mg} / \mathrm{L}$ and neutrophil-to-lymphocyte ratio $>3$. Discharged to home in the next days began to present hemoptisis so he comes to our hospital at August 25th. It was practiced a SARS-CoV-2 quick test that gave IgG (+). It has been made another chest tomography (Fig. 3) that showed a great cavitation with lobar and segmentary bronchus communication. He was evaluated by thorax surgery physician for posibility of surgical treatment.

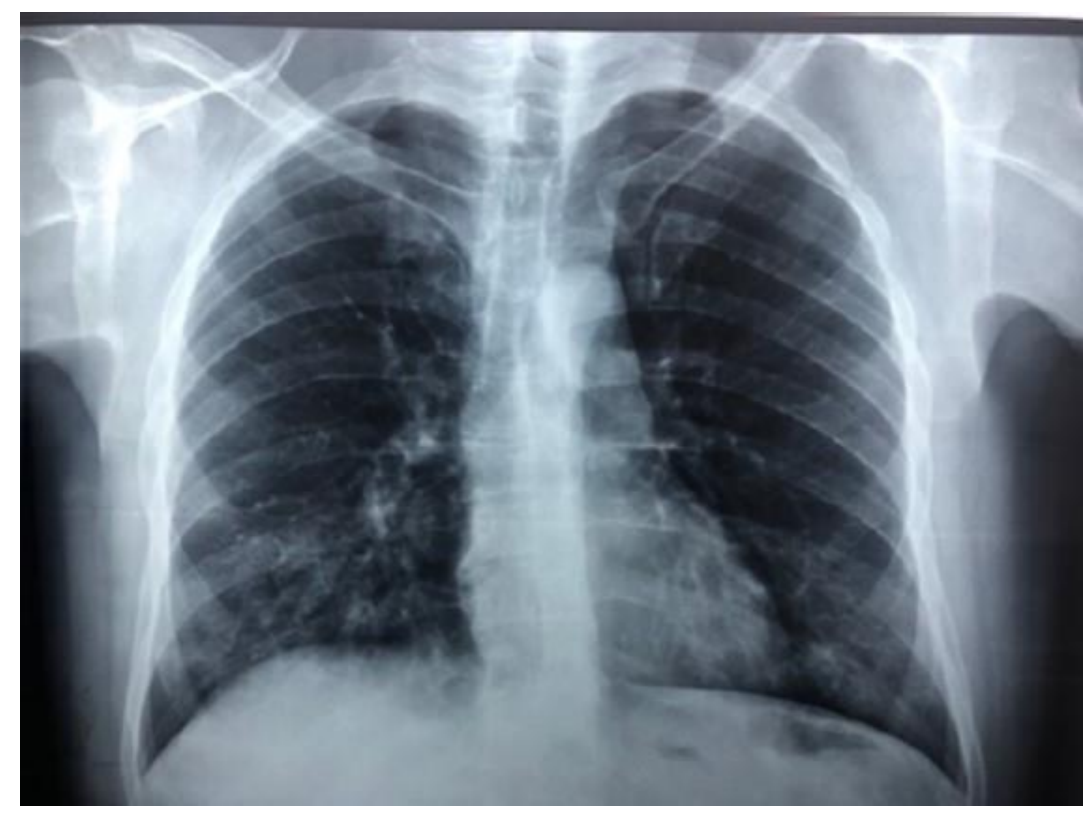

Figure 1: Chest Rx 


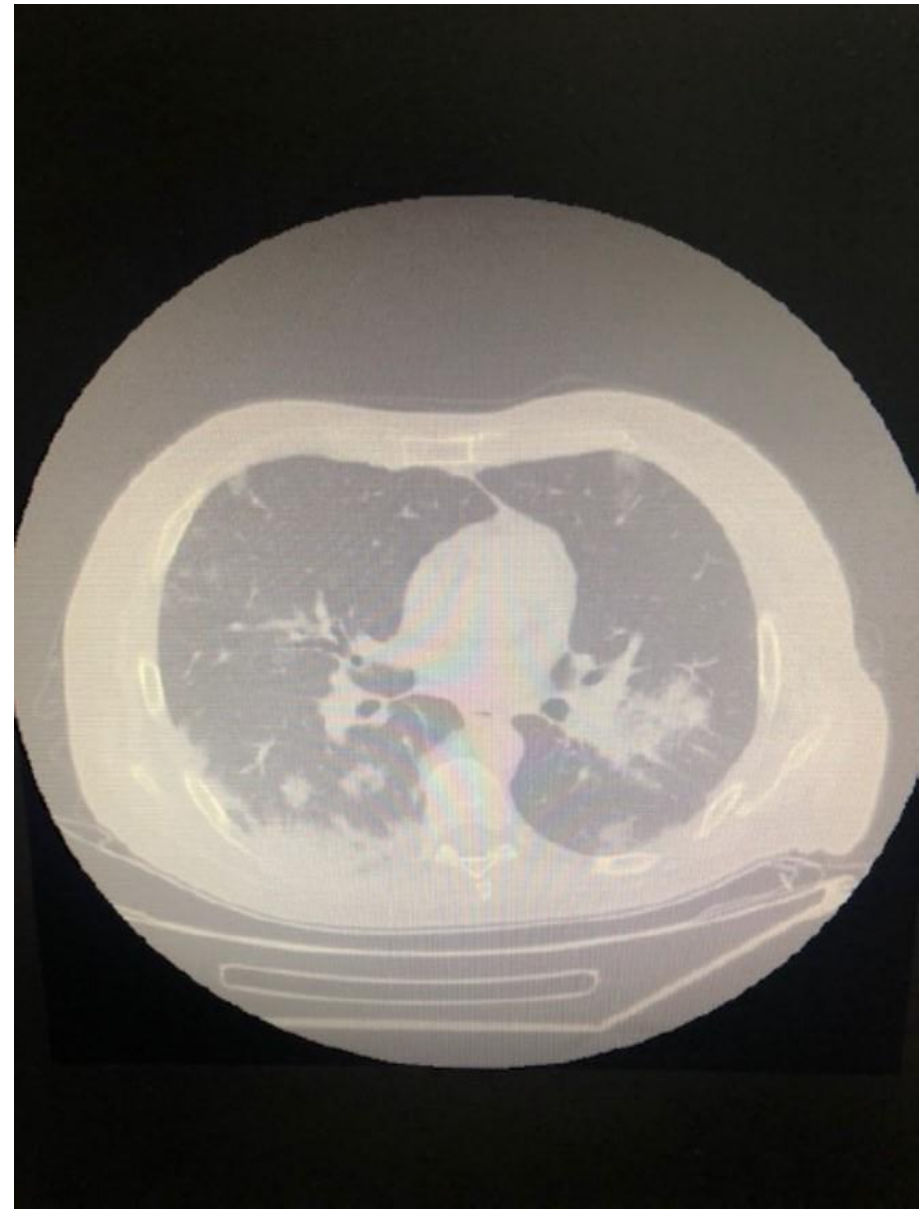

Figure 2: Thoracic CT Scan

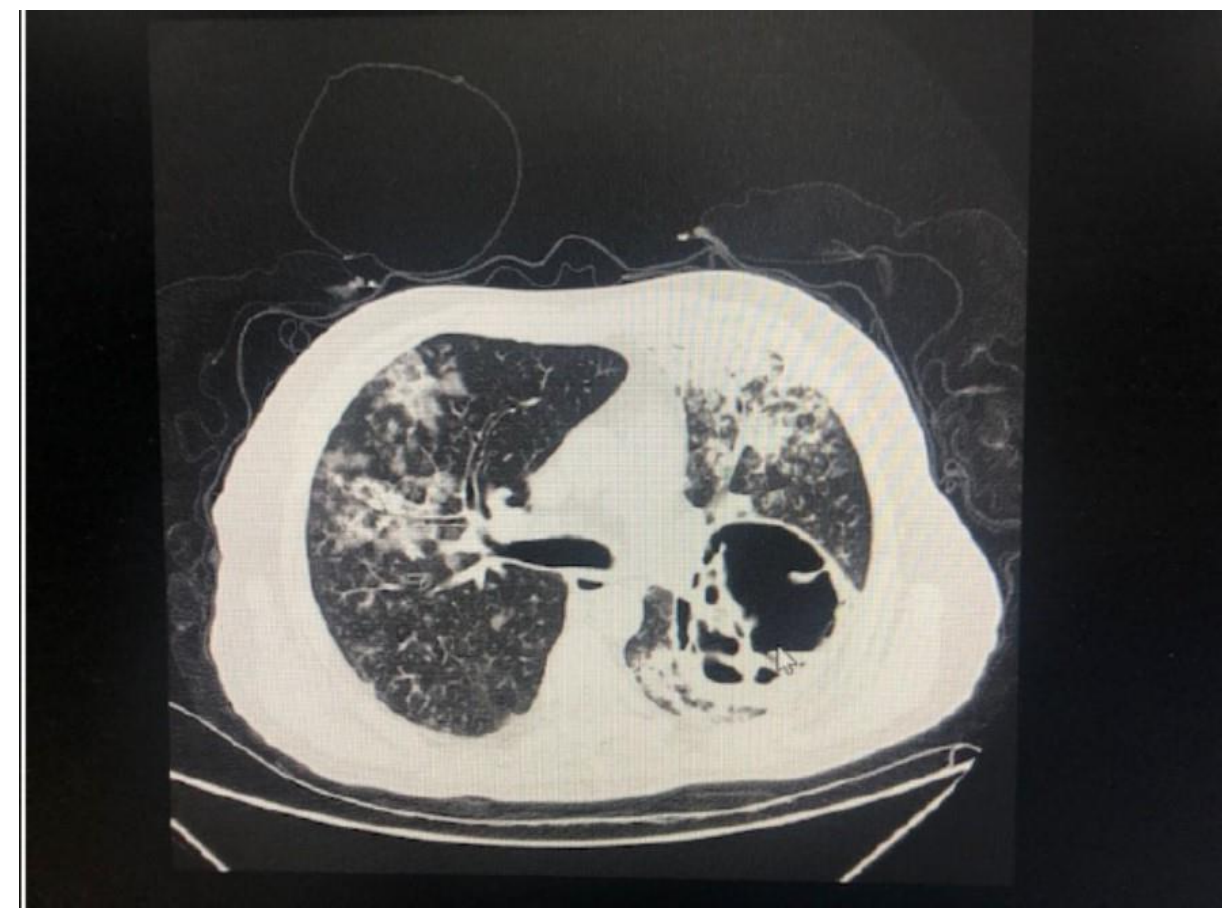

Figure 3: Thoracic CT Scan 